RBS : FGB : PVJ

III -5
DEPARTMENT OF COMTERCE

BUREAU OF STANDAROS

WASH INGION
Letter

Circular

IC-286

\title{
SOIID CARBON DIOXIDE
}

( sugust 13, 1930.)

Solid carbon dioxide compressed into cakes is being manufactured for use as a refrigerant and sold under several trade names, such as "Dry Ice", "Carbonice", itc. These cakes of compressed solid carbon dioxide closely resemble packed snow in appearance and heve a temperature of $-109^{\circ} \mathrm{F}\left(-78.5^{\circ} \mathrm{C}\right)$ or $10 \mathrm{wer}$. Carbon dioxide at room temparatures and atmospheric pressure is a colorless, odorliss gas. It occurs in tha atmosph $ə r e$ to the extent of about $0.03 \%$ by weight, is a product of combustion and respiration, and a by-product of fermentation and of many chemical processes. It can exist as a solid at atmospheric pressura only because of its very low temperature. The cekes ars made by compressing in a mold carbon dioxide snow produced by expanding liouid carbon dioxide at a low t:mperature from a high pressure to atmospheric pressure. In the expansion, part of the liouid is changed to a solid in the form of snow; the rest becomis a gas which is returnod to the compressor for recomprossion and the making of more snow.

Carbon dioxide is different from wat or and most oth $\equiv r$ substances in that it cannot exist as a licuia at atmospheric prosisure (14.7 lbs. pir sq. in. $)^{*}$ only when the pressure is equal to or greatar than 75.1 pounds per square inch ( 5.1 normal atmospheros) and its temp $\rightarrow$ rature $-70^{\circ} \mathrm{F}\left(-56.6^{\circ} \mathrm{C}\right)$ or higher (the "triple point" pressur: and temporeturs) can carbon dioxide exist as a liquid. Hence instead of molting to a liouid as ice does, solid carbon dioxide sublimes, that is, it passos directly from the solid to the gaseous state. This is one of the great advantages of solid carbon dioxide when used as a refrigerant. It does not wet spaces, psckages, and mat irials $r \in f r i g e r a t e d$ with it, end sil the inconvenisnces due to the water from melting ic s are avoided.

An excellent discussion of this subject has been writ$t \in n$ by C.H.MEyers for "Ice and Refrigeretion". Sse "Carbon Dioxide in th: Solid, Liouid and Vspor Stetes", Vol. 76 , pp. 535-37, 1929 . 

Density: The density of the commercial product depends upon the pressures applied in compressing the loose solid into cakes, and possibly on the manner of compressing it. A sample tested at the Bureau of Standards weighed 79 pounds per cubic foot, or 1.27 grams per cc, which may be compared with 57 pounds per cubic foot or 0.92 gram per ce for ordinary ice. crystalline carbon dioxide made by freezing liquid carbon dioxide weighs about 96 pounds per cubic foot, or 1.53 Erams per cc, (International Critical Tables, Vol. I, p. 112 anả Vol. III, p. 43).

Temperature: The temperature of solid carbon dioxide surrounded by pure, gaseous carbon dioxide at a pressure of one normal atmosphere is $-109^{\circ} \mathrm{F}$ or $-78.5^{\circ} \mathrm{C}$ (Irtarnetional Critical Tables, Vol. III, p. 207). In contact with air, its temperature is lower because the partial pressure of carbon dioxide gas is less. In contact with quiescent ary air a temperature of $-114^{\circ} \mathrm{F}$ has been observed and in air curronts $\mathrm{v} \equiv \mathrm{n}$ lower temperatures are observed.

Vapor Pressure: Pure solid carbon dioxiae inclosed in a containgr in contact with its own vapor exerts a prissura, known as the vapor pressur $:$, which varies with the temperature of the solid. The following table, which is an unpublished correlation made at the Bureau of standards of various aata, shows tha variation of the vapor pressure of carbon dioxide with $t \in m-$ perature.

Temperature ${ }^{\circ} \mathrm{F}$

$-69.8$

$-75$

$-80$

$-85$

$-90$

$-95$

$-100$

$-105$

$-110$

$-120$

$-130$

$-140$
Absolute Pressure $1 b=\sqrt{\mathrm{sq} \cdot \mathrm{in} \text { Normal }}$ Atmospheres $\frac{\text { Temperature }}{{ }^{\circ} \mathrm{C}}$

5.11

4.20

3.46

2.83

2.31

1.87

1.51

1.21

0.97

0.61

0.37

0.22
$-56.6$

$-59.4$

$-62.2$

$-65.0$

$-67.8$

$-70.6$

$-73.3$

$-76.1$

$-78.9$

$-84.4$

$-90.0$

$-95.6$ 

Tho nomal atmosphere is definod as a pressure exerted by a column of mercury $7 . \mathrm{cm}$ high und er standard conditions and is vory closely ecual to a pressuro of 14.7 pounds per square inch.

Iatent Heat of Sublimation: In passing from the solid to the gaseous state at atmospheric pressure carbon dioxide takes up 248 Btu of heat energy per pound, or 138 celories per gram, (Intérnational Critical Tables, Vol. V, p. 138). A Btu (British Thermal Unit) is by dofinition the quantity of hat energy required to raise tho temperature of one pound of water $1^{\circ} \mathrm{F}$.

Iatant Heat of Fusion: In passing from the solid to th 1 iauid state at its "tripls point" $\left(-70^{\circ} \mathrm{F}\right.$ or $-56.6^{\circ} \mathrm{C}$ ) carbon dioxide takes up 82 Btu of hoat energy par pound, or 45.3 calories por gram (International Critical Tablos, Vol. V, p. 131).

Specific Heats of Solid and Gascous Carbon Dioxide at Low Temperatures: The specific heat of solid carbon dioxide at $-109^{\circ} \mathrm{F}\left(-78.5^{\circ} \mathrm{C}\right)$ is 0.31 Btu per pound par ${ }^{\circ} \mathrm{F}$ or caloris per grem $p=r{ }^{\circ} \mathrm{C}$; that is, in order to raise or lower the timp: rature of ons pound of solid carbon dioxide $1^{\circ} \mathrm{F}$ at $-109^{\circ} \mathrm{F}, 0.31$ Btu of heat energy has to be addad to or tak $n$ from the solid, accordingly as its t:mparature is to $b$ raised or lowered (Int amational Critical Tables, Vol. V, p. 95). In the $t \equiv$ mpsature int ervel between $-109^{\circ} \mathrm{T}^{\circ}\left(-78.5^{\circ} \mathrm{C}\right)$ end $+32^{\circ} \mathrm{F}\left(0^{\circ} \mathrm{C}\right)$ the mean specific heat of tha vapor is about 0.19 Btu par pound $p a r{ }^{\circ} \mathrm{F}$ or caloria per gram per ${ }^{\circ} \mathrm{C}$. Therefora one pound of carbon dioxids vapor after subliming from tha solid will absorb 0.19 Btu for each degree rise in tempirature bstween $-109^{\circ} \mathrm{F}$ end $+32^{\circ} \mathrm{F}$ (Int cal Tables, Vol. V, p. 80).

Refrigarating Effect: Besi das tha refrigerating effect aue to the chang? of stats, there is the additional $r \in f r i g s r a t i n g$ effect of 27 Btu per pound st $32^{\circ} \mathrm{F}(15$ calorias per grem s.t $0^{\circ} \mathrm{C}$ ) 3 cue. I to th $\approx$ emount of her.t which the cold cerbon dioxide vepor et $-109^{\circ} \mathrm{F}\left(-78.5^{\circ} \mathrm{C}\right)$, after subliming from tho solid, absorbs in baing warmed to $32^{\circ} \mathrm{F}\left(0^{\circ} \mathrm{C}\right)$. Hance on 3 pound of cerbon dioxide absorbs $275 \mathrm{Btu}$, or 153 celorias per gram, in chrnging from a solid at $-109^{\circ} \mathrm{F}\left(-78.5^{\circ} \mathrm{C}\right)$ to a gas at $32^{\circ} \mathrm{F}\left(0^{\circ} \mathrm{C}\right)$. Tris is epproximat:ly equal to twies the smount of heat, 144 Btu p.rr pound or 79.6 oc.loriss por gram absorbed by ice on $m: 1$ ting et $32^{\circ} \mathrm{F}\left(0^{\circ} \mathrm{C}\right)$; c.nd, s.s this is often 

expressad, one pound of solid carbon dioxide hes approximotely tha same refrigarating effect at $32^{\circ} \mathrm{F}$ ss two pounds of ice.

Mixtures of ice and salt ars used to produce temperatures below $32^{\circ} \mathrm{F}$ and to refrigurete speces at temparetures balow those obtainable with ice clone. The host asorba a by ? pouna of r mixture of ics nd sc.lt when the ice milts rnd the scolt dissolves - its refrigercting effect - is smeller then the heat rbsorb d by one pound of ic $s$, inssmuch $\mathrm{s}$ s sound of the mixture contcins less the.n $\varepsilon$ pound of ic:, the so.lt e.ffecting tha result only to a compretivaly smell ext:nt. Moreover, the letent hect of fusion of ice is smeller ct low $=r$ temperatures then it is c.t $32 \circ \mathrm{F}$, and some of the ice is maltsd in cooling tha mixtur: of ics snd selt to tha reduced tempersture. Thes: effects lowir som whet the smount of refrigeration which cen be obtained from ics when it is used with salt. $H \equiv n c ?$, the ratio of the refrigerating effact of solid cerbon dioxide to thet of ice used with salt is great: $x$ then the ratio of thoir refrigs $r-$ eting effects wh $=n$ ic $=$ is $u s=d$ elone.

As solid carbon dioxide is ordinerily used ss $s$ refrigerent, the cold cerbon dioxide ges ss $_{\text {it }}$ sublimes from the solid displeces from the space to be rafrigs reted first tha eir end then th $\Rightarrow$ werm cerbon dioxide gas. Geseous cerbon dioxide is e. bettar heet insulstor then eir, the retio of the hest conducted by cerbon dioxide to that conducted by $=$ ir und $r$ the ssme conditions et $32^{\circ} \mathrm{F}$ bsing 0.6 . Ths heet, howevar, thet passes from 2 warm :xt arior into a rafrigerated specs depends, rmong other things, upon the insulating properties and upon the thickness of the sepereting we Ils as will as upon the thirmel conductivity of the gas inside. The better the hest insuletion of the separating wils, tha relatively less important is the thermel conductivity of the gas inside.

Uses: Solid cerbon dioxide has been used most ext: nsi $\overline{v e l y}$ for refrigerating ice cresm in tronsit. It is nso used for refrigirating shipments of oth perisheble commoditiss.* In leborrtorias it is usad to some extent for th for testing and exp rimmte.l work.

* Cerbon dioxide ctmospheres heva besn found to produce hermful effects on living things kept in thim. For this $r$ sason carbon dioxide atmospheres exercise a preservative 

action on meats and fish by impeding the growth of bacteria in them (See reference (10) of the "Bibliography" at the end of this lettor circular). Since fruits, even after they are picked from the plant, are living things which take up oxygen and give off carbon dioxide, high concentrations of carbon dioxide in an atmosphere, in which they are stored, for short times or smaller concentrations for longer times are harmful. For further information on this subject, the reader is referred to the Bureau of Plant Industry, Department of Agriculture, Washingt on, D. C.

Machinery for Making Solid Carbon Dioxide: The names and addresses of some companies which manufacture machinery used in the production of solid carbon dioxide are ziven below in alphabetical order.

(1) Brunswick Kroeschell Company, New Brunswick, Naw JErs

(2) Dry Ice Equipment Corporation, 52 Vanderbilt Avenue, New York.

(3) Frick Company, Waynesboro, Pa.

(4) Wittenmeier Machinery Company, Chicago, Ill.

(5) York Manufacturing Company, York, Pa.

Bibliography: The following is a list of $r \in f e r e n-$ ces to papers on the menufacture and use of solid carbon dioxide as a refrigirant, arranged in the order of publication:

(1) Several Articles on Dry Ics in "The Canadian Fisherman", Gardenvale P. S. Canada; Vol. ll, No. 5 (May, 1924).

(2) "Solid $\mathrm{CO}_{2}$ in the Fish Industry", by H. F. Taylor in Ice and Refrigeration; Vol. 71 , pp. 211-13 (1926).

(3) "Ice that IN Its to a Gas", by D. H. Killeffer, Scientific American; Vol. 137, pp. 220-222 $(1927)$.

(4) "Solid $\mathrm{CO}$ \& $\mathrm{N} \in \mathrm{w}$ Commercial Refrigarant", by D. H. Killefer, Journal of Industrial and Engineering Chemistry; Vol. 19, pp. 192-5 (1927). (5) "The Field of Dry Ice in Modern Refrig:ration", by I. W. Martin, Jr., Refrigere.ting Engineering; Vol. 15, pp. 33-34 (1928).

(6) "The Commercial Fiuld for Dry Ice", Rafrigereting Engineering; Vol, 16, No. 2, pp. 45-46 (August, 1928).

(7) "Msnufecture of Cerbon Dioxide", by H. E. Howe, Joumal of Industrial and Engine ering Chomistry, Vol. 20, pp. 2091-4 (1928). 

(8) "Crrbon Dioxide in the Solid, Liouid, end Vepor Ststes", by C. H. Mey ors, Ice snd Rsfrigeretion; Vol. 76 , pp. 535-7, June, 1929.

(9) "Dry Ic 3 M nufecture", by J. C. Goosmen, Rafrigerating Engimering; Vol. 18, p. 155 ( $D \in-$ cembor, 1929).

(10) "Corbon Dioxide Preservation of Mest end Fish", by D. H. Killeffer, Journel of Industriel and Enginesing Chemistry; Vol. 22, pp. 140-3 (1930).

(11) "Hydrated Solid Carbon Dioxida", by W. S. JoSephs on, Refrigarating Engin: ering; Vol. 19, p. 25 (1930).

(12) "The Design end Sp=cificetions of a Dry Air Refrigerator Cer", by C. C. Palmer, Rofrig rat ing Engin ering; Vol. 19, No. 2, p. 67 (1930).

(13) "Solia $\mathrm{CO}_{2}$ as E. Refrigerent", by $\mathrm{F}$. W. Reba, R Prigersting Enginsering; Vol. 19, No. 5, pp. $143-145$ (1930).

(14) "Truck Body Refrig:retion", by Willicm E. Beird, Refrigercting Enginsering, Vol. 20, p. 16 $(1930)$. 


